\title{
THE ECONOMIC SITUATION OF THE HOTEL SECTOR IN POLAND IN 2003-2012
}

\section{MARIA BYSZEWSKA-DAWIDEK}

\begin{tabular}{|c|c|}
\hline & $\begin{array}{l}\text { Warsaw School of Tourism and Hospitality Management, POLAND } \\
\text { e-mail: m.byszewska@intur.com.pl }\end{array}$ \\
\hline $\begin{array}{l}\text { RECEIVED } \\
\text { ACCEPTED }\end{array}$ & $\begin{array}{l}17 \text { January } 2016 \\
1 \text { April } 2016\end{array}$ \\
\hline JEL & \\
\hline CLASSIFICATION & 014 \\
\hline KEYWORDS & supply, accommodation establishments, hotels, bed places in hotels, revenue \\
\hline ABSTRACT & $\begin{array}{l}\text { On the basis of published and unpublished statistical materials, the article discusses changes in hotel manage- } \\
\text { ment in Poland in 2003-2012. } \\
\text { In addition to a brief introduction, the first part of the article describes the supply-side aspects of the hotel } \\
\text { industry in Poland, the position of hotels among Poland's accommodation facilities. It discusses the importance } \\
\text { of hotels as tourist accommodation establishments and presents establishments, rooms and bed places in } \\
\text { hotels in terms of quantity and their increases in the corresponding periods as well as changes in the numbers } \\
\text { of establishments and of bed places in hotels by category. } \\
\text { The second part of the article discusses the economic situation of large and medium-sized hotels in 2003-2012 } \\
\text { and that of small hotels in 2003-2010. It analyses revenue, gross and net profit (or loss) as well as gross and } \\
\text { net profitability. }\end{array}$ \\
\hline
\end{tabular}

\section{Introduction}

This article is a follow-up to the research done at the Institute of Tourism in 2003-2012 and written within the framework of the project entitled Rynek hotelowy w Polsce 2015 ('The Hotel Market in Poland 2015'), implemented at the Warsaw School of Tourism and Hospitality Management under the supervision of Dr Krzysztof Łopaciński and financed by the Ministry of Science and Higher Education. 
In recent years hotels in Poland have markedly gained in importance as tourist accommodation establishments, which is confirmed by the main supply indicators. The upward trend in the segment concerned has been noted for years and appears to be a permanent development, even though the growth rate has varied. It is consistent with the general European and global trends in the development of tourism infrastructure. There are a number of indications that this trend will also be observed in the coming years, although it may slow down due to the crisis situation in the world economy.

National and international statistics on the supply of tourist accommodation services show a separate category of hotels and similar accommodation, including motels and boarding houses. According to the Polish public statistics (Turystyka..., 2009), accommodation services are provided by collective tourist accommodation establishments divided into two main groups: hotel establishments and other accommodation establishments. The first group includes hotels, motels and boarding houses as well as other hotel establishments, a separate subgroup distinguished in GUS statistics since 2004. It covers accommodation establishments providing services characteristic of hotel establishments (e.g. making beds, room service, etc.), but without completed categorisation proceedings or uncategorised (for instance, establishments performing the tasks of hotels, motels or boarding houses and not assigned to any specific category). The information contained in this article solely concern hotels and part of hotel establishments included in GUS statistics as hotels during categorisation.

The statistical information provided in the article is contained in publications of the GUS Central Statistical Office of Poland (Turystyka..., 2009-2015), reports of the Institute of Tourism (Dziedzic, Łopaciński, 2003) and (Byszewska-Dawidek, Dziedzic, Jagusiewicz, Łopaciński, 2006-2010), as well as in unpublished statistical materials prepared by GUS and commissioned by the Institute of Tourism in 2003-2014.

\section{The position of hotels among accommodation establishments in Poland}

As compared to other European countries, hotels in Poland continue to account for a relatively limited share of all the collective tourist accommodation facilities, with the total number of 7,300 establishments and 639,100 bed places in 2014, even though for many years hotels have been the most numerous group among the 18 types of accommodation establishments distinguished in statistics, ahead of the previously dominating holiday centres. In 2014, as in the previous year, the share of hotels in the domestic accommodation resources increased again to $30.1 \%$. This upward trend has continued for several years, except for a fall noted in 2012 . The proportion of hotels in the total number of bed places is slightly higher (35.6\%). At the same time, this share is much greater, i.e. $50 \%$, with regard to all-year establishments.

Table 1. Percentage share of hotels in the number of establishments and in the number of bed places in collective accommodation in: 2000, 2007 to 2014

\begin{tabular}{lccccccccc}
\hline \multicolumn{1}{c}{ Specification } & 2000 & 2007 & 2008 & 2009 & 2010 & 2011 & 2012 & 2013 & 2014 \\
\hline Establishments & 11.8 & 20.3 & 21.7 & 23.4 & 25.0 & 26.8 & 21.2 & 29.5 & 30.1 \\
Bed places, total & 14.6 & 24.2 & 26.1 & 27.3 & 29.0 & 30.8 & 29.3 & 33.3 & 35.6 \\
All-year bed places & 29.1 & 40.0 & 40.2 & 41.6 & 42.5 & 44.6 & 43.1 & 47.6 & 50.0 \\
\hline
\end{tabular}

Source: study by the Institute of Tourism based on GUS data. 
According to GUS data (Turystyka..., 2015), in the summer season of 2014 in Poland there were a total of 2,250 hotels with 114,000 bedrooms, offering tourists 227,500 bed places. In comparison with 2013 , it meant a rise in the number of hotels, bedrooms in hotels and bed places by $6.8 \%, 7.8 \%$ and $9.1 \%$ respectively.

Following previous downswing years, the results of both 2014 and several years before may reflect a reversal of the downward trend in the rate of growth in the number of hotel establishments, bedrooms and bed places in Polish hotels.

Table 2. Growth in the number of bedrooms in hotels in 2001 and 2008-2014 (in \% on the previous year)

\begin{tabular}{ccccccccc}
\hline Specification & 2001 & 2008 & 2009 & 2010 & 2011 & 2012 & 2013 & 2014 \\
\hline Growth in the number of bedrooms in hotels & 3.0 & 10.2 & 6.3 & 6.7 & 4.9 & 5.4 & 5.7 & 7.8 \\
\hline
\end{tabular}

Source: IT study based on GUS data.

\section{Categories of hotels in 2014}

In 2014 the total number of hotels assigned to categories $1^{*}$ to $5^{*}$ was 2,153. In addition, 97 hotels were during categorisation. Categorised establishments offered 111,100 bedrooms and 221,500 bed places. The Polish hotels mostly render all-year services. The overall number of seasonal facilities was seven: four $2^{*}$ establishments, one $1^{*}$ establishment, one $3^{*}$ establishment and one establishment during categorisation, with a total of merely 1,900 bed places $(0.9 \%$ of the overall number).

As in the previous years, $3^{*}$ hotels constituted the most numerous group also in 2014 . They were followed by $2^{*}$ establishments. The two groups combined accounted for over $72 \%$ of the total number of hotels and for $59 \%$ of bed places in hotels. The respective positions of those groups in the structure of the Polish hotel establishments have not changed dramatically in recent years. Establishments of major importance continue to be $2^{*}$ and $3^{*}$ hotels whose capacity has long been close to $70 \%$ in relation to all the hotel facilities.

Apparently, the resources of hotels of higher categories, despite their continuous extension, still represent a minor share in all the hotel facilities. In $20145^{*}$ and $4^{*}$ hotels, accounting for a mere $15.8 \%$ of the total number of hotels, offered $32.9 \%$ of bed places in domestic hotels. Recently the group in question has been reinforced with 50 new establishments, whereas their capacity has increased by $16 \%$ on the previous year. It is worth emphasising that top-standard hotels are primarily found in large cities and agglomerations. There are a great deal more cheaper establishments offering lower standards. The groups of $2^{*}$ and $1^{*}$ hotels account for over $32.8 \%$ of all the establishments and for $23.4 \%$ of bed places.

Changes in the overall hotel supply were not evenly distributed between categories. In 2013-2014 the greatest increase in number concerned $3^{*}$ hotels, growth in the number of $4^{*}$ establishments was also considerable. Furthermore, the most significant increases in the number of bed places in hotels were also found in $3^{*}$ and $4^{*}$ establishments. Relative changes presented a somewhat different picture. The resources of top-class hotels showed the highest percentage growth rates, in terms of both establishments and bed places. 
Table 3. Changes in the numbers of establishments and bed places in hotels by category in 2013-2014

\begin{tabular}{|c|c|c|c|c|c|c|c|c|}
\hline \multirow{3}{*}{ Category } & \multicolumn{4}{|c|}{ Establishments (hotels) } & \multicolumn{4}{|c|}{ Bed places } \\
\hline & \multicolumn{2}{|c|}{ number } & \multicolumn{2}{|c|}{ change 2013-2014 } & \multicolumn{2}{|c|}{ number (thousand) } & \multicolumn{2}{|c|}{ change 2013-2014 } \\
\hline & 2013 & 2014 & number & $\%$ & 2013 & 2014 & thousend & $\%$ \\
\hline $5^{*}$ & 47 & 55 & 8 & 17.0 & 11.3 & 13.0 & 1.7 & 15.0 \\
\hline $4^{*}$ & 261 & 303 & 42 & 16.1 & 53.5 & 62.0 & 8.5 & 15.9 \\
\hline $3^{*}$ & 964 & 1,056 & 92 & 9.5 & 85.5 & 93.2 & 7.7 & 9.0 \\
\hline $2^{*}$ & 565 & 572 & 7 & 1.2 & 41.0 & 41.2 & 0.2 & 0.5 \\
\hline $1^{*}$ & 171 & 167 & -4 & -2.3 & 11.6 & 12.1 & 0.5 & 4.3 \\
\hline During categorisation & 99 & 97 & -2 & -2.0 & 5.7 & 6.1 & 0.4 & 7.0 \\
\hline Total & 2,107 & 2,250 & 143 & 6.8 & 208.6 & 227.6 & 19.0 & 9.1 \\
\hline
\end{tabular}

Source: IT study based on GUS data.

Specific categories differ in the size of establishments; the greatest capacity characterised $5^{*}$ hotels, with an average of 236 bed places. The groups of $4^{*}$ and $3^{*}$ hotels also had capacities above or close to the national average (101 bed places), i.e. 205 and 88 bed places respectively. The majority of $2^{*}$ and $1^{*}$ hotels are small establishments with a capacity of 72 bed places. Similar relations were also observed in previous years. This proves the general rule that the higher the category the greater the capacity of an average hotel establishment.

\section{The economic situation of hotels - introductory information}

This economic analysis divides the economic operators under examination into two groups. One includes those employing over 9 persons. It covers economic operators having declared their object to be hotel activities and been classified in accordance with the Polish Classification of Activities (Polska Klasyfikacja Działalności - PKD) under section $\mathrm{H}$ (hotels and restaurants), division 55 (hotels and restaurants), group 55.1 (hotels). The following calculations regarding financial management in hotels were based on aggregated data from annual statements, F-02 forms from the Central Statistical Office (GUS). Full statistical surveys by GUS on the basis of the F-02 form cover all the large and medium-sized units.

The other group of entities includes enterprises with up to 9 persons employed. Information concerning the main data on the object of such enterprises, owing to their great number, is obtained from a sample survey based on the SP-3 form.

Each unit in the sample is assigned a weight allowing to generalise the results. The weights represent the ratio of the number of units in the whole population surveyed to the adjusted sample, i.e. excluding units having suspended business activity, wound up, having failed to start economic activities or beyond the scope of the survey.

The economic analysis in that group was carried out until 2010 since it was impossible to obtain data for the subsequent years.

\section{Analysis of total revenue and of the profit (or loss) of hotels}

Throughout the period covered, i.e. in 2003-2012, the number of hotels subject to full reporting obligations, i.e. those with more than 9 persons employed, was on the increase and their total revenue went up as well. The year 2009 was an exception: despite a rise in the number of hotels by as many as 28 establishments, their revenue 
dropped from PLN 4,823.0 million in 2008 to PLN 4,429.5 million in 2009. The following years only witnessed growth in revenue.

Table 4. Total revenue of hotels with more than 9 persons employed in 2003-2012 (PLN million)

\begin{tabular}{ccc}
\hline Year & Total revenue (PLN million) & Number of hotels \\
\hline 2003 & $2,489.9$ & 284 \\
2004 & $3,544.8$ & 339 \\
2005 & $3,797.8$ & 363 \\
2006 & $3,957.5$ & 381 \\
2007 & $4,763.0$ & 396 \\
2008 & $4,823.0$ & 419 \\
2009 & $4,429.5$ & 447 \\
2010 & $4,724.8$ & 458 \\
2011 & $5,777.4$ & 498 \\
2012 & $5,818.1$ & 519 \\
\hline
\end{tabular}

Source: calculations of the Institute of Tourism based on unpublished GUS data.

The greatest total revenue in the decade was obtained by hotels employing over 9 persons in the last period covered, i.e. in 2012 - their sales reached PLN 5,818.1 million. The figure was PLN 40.7 million higher than in 2011 and PLN 3,328.2 million higher than in 2003. In addition, 2012 saw the highest number of hotels filing reports - 519 establishments, i.e. 21 hotels more in comparison with the previous year and 235 establishments more than ten years before, i.e. in 2003.

The number of hotels employing up to 9 persons ranged from 979 units in 2001 to 2,396 units in 2010. The first three years saw an upward trend in the number of small hotels. In 2004 their number significantly dropped, below the 2002 figure. In 2005 it rose again to 1,270, which was followed by a slight decline in 2006. In the four subsequent years under analysis the number of small hotels went up only.

The total revenue of small hotels was characterised by trends similar to those in the number of hotels since the two indicators are strongly correlated. After three years of continuous growth there was a fall in revenue in 2004. It was connected with a decrease in the number of hotels. A rise was seen again in 2005 . The total revenue of hotels employing up to 9 persons was then PLN 487.7 million, up by PLN 84.1 million on the previous year. The revenue continued to augment in the subsequent years. The peak year was 2010. The total revenue amounted to PLN 1,176.6 million, nearly double the 2008 figure.

The Polish market is definitely dominated by small hotels, i.e. those with up to 9 persons employed. They represent a vast majority of all the hotels operating in the Polish market. But in 2010 their total revenue was a mere $20 \%$ of the total revenue obtained by all the hotels in the market.

The profit of hotels employing more than 9 persons widely varied over the ten years under analysis. It ranged between very different values, from extremely low to very high. The highest gross profit earned by hotels in the ten years covered was noted in 2012. It jumped from PLN 198.9 million in 2011 to PLN 640 million. Gross profit was also very high in 2007, at PLN 608.5 million. The following year, 2008, witnessed very low gross profit: PLN 11.8 million. The reason was that the group of hotels employing 50 to 249 persons reported an enormous loss, the financial 
result obtained by that group was negative at PLN -82.1 million. The subsequent two years of 2009-2010 saw a recovery, with respective profits of PLN 219.6 million and PLN 188.4 million. Profits further improved in 2012.

In 2003 the gross profit of small hotels, in spite of a significant rise in the number of small hotels as well as very high total revenue obtained by those hotels, was not substantial. It did not increase until 2004, to PLN 36.7 million. In 2005-2006 there was a fall in gross profit. In 2006 it turned into a loss of PLN 2.7 million. It was the lowest value reported by small hotels in 2003-2012. In 2007 gross profit showed a rise, to decline again to PLN 20.6 million in 2008. In 2010 gross profit amounted to PLN 140.0 million. It was the best financial performance of small hotels throughout the period in question.

\section{Profitability of hotels}

Profitability is closely correlated with revenue and profit (or loss).

The year 2003 was characterised by good profitability of large and medium-sized Polish hotels, followed by significant improvement in 2004 when gross and net profitability of Polish hotels was $11.3 \%$ and $9.8 \%$ respectively. It meant the materialisation of the projections of Polish hotel owners that the enlargement of the European Union would be a new driver of economic growth in a united Europe, therefore also in Poland. The year 2005 saw a downturn, both gross and net profitability as well as gross profit declined: gross profitability fell to $9.2 \%$, whereas net profitability dropped to $7.7 \%$. It means that the period concerned witnessed diminished profitability of Polish hotels. There was a rise in the following two years, but in 2008 gross and net profitability slumped to $0.2 \%$ and $-0.7 \%$ respectively. It was related to the general economic downswing, hampering international tourism and business traffic, and to the poor financial standing of the Polish population, limiting demand for hotel services. The years 2009-2010 saw a recovery: gross profitability went up to $5 \%$ and $4 \%$ respectively, whereas net profitability increased to $4 \%$ and $2.9 \%$ respectively. After another fall in 2011, 2012 proved to be the peak year in terms of profitability: gross profitability jumped to $11.0 \%$ and net profitability to $9.8 \%$.

As regards small hotels, they showed the highest gross profitability in the last period covered, i.e. 2010. It was nearly $12 \%$. Throughout the period under analysis small hotels never were as profitable. Their profitability was always lower, even though they performed quite well in certain periods. It is worth poiting out the year 2004, with high profitability of $9.1 \%$. In 2005 the gross profitability of small hotels dropped nearly by half against 2004 , from $9.1 \%$ to $5.2 \%$. The lowest profitability of small hotels was noted in 2006 when the value was negative, at $-0.5 \%$. In the following two years their profitability slightly improved, but it never reached the favourable levels recorded in the previous years. In 2008 it was merely $3 \%$.

\section{Conclusions}

The hotel market in Poland has been developing buoyantly for several years. The market has been growing not only through putting new hotels into use, but also through extending and modernising existing establishments or adapting other buildings. The share of hotels in the Polish economy has been on the rise as well. The hotel business is regarded as the most profitable tourism industry. Despite periodical decreases in profitability indicators, the sector has been generating relatively the highest profits, driven by a high growth rate of capital formation in the industry concerned, which allowed to achieve an advantageous market position and earlier adjustment to changes in demand for tourism services. 
The profitability of the sector is positively correlated with the number of visits by foreigner nationals to Poland. As Poland ranked lower globally in terms of number of inbound tourism trips, the profitability of the hotel industry went down at the same time.

The number and composition of hotels in construction suggest that the most important source of income in the hotel sector will be individual tourism. Therefore, the vast majority of such establishments are two- or three-star hotels, mostly built in typical tourist destinations as well as in large cities.

Presumably, the most popular hotels in Poland will be independent establishments built by Polish investors rather than chain hotels. They are preferred by Polish tourists and foreign visitors usually appreciate them as well.

\section{References}

Byszewska-Dawidek, M., Dziedzic, T., Jagusiewicz, A. \& Łopaciński, K. (2006). Rynek hotelowy 2006. Dynamika, wskaźniki, prognozy. Warszawa: Instytut Turystyki, Wiadomości Turystyczne.

Byszewska-Dawidek, M., Dziedzic, T., Jagusiewicz, A. \& Łopaciński K. (2007). Rynek hotelowy 2007. Dynamika, wskaźniki, prognozy. Warszawa: Instytut Turystyki, Wiadomości Turystyczne.

Byszewska-Dawidek, M., Dziedzic, T., Jagusiewicz, A. \& Łopaciński, K. (2009). Rynek hotelowy 2009. Dynamika, wskaźniki, prognozy. Warszawa: Instytut Turystyki, Wiadomości Turystyczne.

Byszewska-Dawidek, M., Dziedzic, T., Jagusiewicz, A. \& Łopaciński, K. (2010). Rynek hotelowy 2010. Dynamika, wskaźniki, prognozy. Warszawa: Instytut Turystyki, Wiadomości Turystyczne.

Byszewska-Dawidek, M., Dziedzic, T. \& Łopaciński, K. (2012). Rynek hotelowy 2012. Dynamika, wskaźniki, prognozy. Warszawa: Instytut Turystyki, Wiadomości Turystyczne.

Dziedzic, T. \& Łopaciński, K. (2003), Rynek usług hotelarskich w Polsce. Warszawa: Instytut Turystyki, Wiadomości Turystyczne.

Turystyka w 2008 r. Informacje i opracowania statystyczne (2009). Warszawa: GUS.

Turystyka w 2014 r. Informacje i opracowania statystyczne (2015 and the previous editions). Warszawa: GUS.

Cite this article aS: Byszewska-Dawidek, M. (2016). The economic situation of the hotel sector in Poland in 2003-2012. European Journal of Service Management, 18 (2), 5-11. DOI: 10.18276/ejsm.2016.18-01. 
